\title{
BASIC ASPECTS OF RURAL SOCIAL INFRASTRUCTURE DEVELOPMENT
}

\author{
YARKOVA Tatiana Mikhailovna ${ }^{1}$ \\ ${ }^{1}$ FSBEI HE «Perm State Agro-Technological University named after Academician D.N. Pryanishnikov» (RUSSIA) \\ Email: tanyayarkova@ya.ru
}

\begin{abstract}
The social infrastructure of rural areas is of particular importance when considering issues of both an economic and social nature. Both production and non-production rural areas necessitate the availability of social facilities. The main purpose of social infrastructure facilities nowadays and in the past of rural and urban areas development is to meet the needs of the population. At the same time, social infrastructure defines the basis for the level and quality of life of civil society. Its condition is an indicator of the territorial development and provides opportunities for innovative development and investment attraction. For many years now, the rural social infrastructure has been in poor condition in Russia. Problems are observed in the living conditions of citizens, in elements of residential properties improvement, undeveloped system of medical and educational services, unavailability of cultural and leisure facilities, and so on. Due to such a negative state of the rural social sphere, problems arise with the demographic situation and the production sphere in terms of the inability to attract highly qualified personnel. The Program for the Sustainable Development of Rural Territories developed by the Government of Russia holds back the general, intensively negative situation, and is fundamentally changing it in some regions of the country. The paper presents the results of the implementation of the main Program directions and gives some recommendations on its further implementation and development of the rural social infrastructure.
\end{abstract}

Keywords: rural sphere, infrastructure, rural areas, socio-economic development, program

JEL: R11

UDC: 338.431

COBISS.SR-ID 28651785

\section{Introduction}

The development of rural areas is currently important and is determined by the considerable attention on the part of state authorities from the standpoint of socio-economic development of those areas. A well-known fact is that social infrastructure and its development form the general status and development status of a particular rural territory, as well as the level and quality of life of its population. Therefore, the priority aspect in the rural development is the development of social infrastructure, in particular within the framework of housing and communal services, social and cultural facilities and social services [4]. The development of these components of the rural social infrastructure will lead to a more 
complete satisfaction of the rural residents' needs which are an elementary norm of life: good working and living conditions, education, recreation, medical care, etc. [2].

The formation of social infrastructure is almost directly related to the development of the working environment. Almost all business entities engaged in agricultural production as part of industrial and economic activities are located in close proximity to rural territories.

Therefore, there is a close relationship between the development of social and industrial infrastructure.

Along with this, one cannot fail to note the role of the Russian state in managing the agricultural sector and the socio-economic development of rural areas. This is evidenced by the availability of program-targeted management of the agricultural sector of the economy until 2025, within the frameworks of which there are implemented:

- Support in the form of governmental grants and subsidies to agricultural producers;

- Technical and technological modernization of business entities in agriculture;

- Activation of land policy, the purpose of which is the rational use of agricultural land and maintaining land fertility;

- Other measures [6].

The implementation of many program-targeted tools is aggravated by a shortage of highly qualified and professionally trained personnel. Some agricultural producers have a negative impact on the state of economic activity through a shortage not only of highly qualified personnel, but also of the workforce as a whole [13]. All this negatively and conclusively affects the social component of rural development.

It can be stated that social infrastructure in the system of social reproduction and regional economic grow this of great importance. However, it is practically impossible to talk about social infrastructure as a whole due to its heterogeneity. In particular, rural areas are mostly characterized by underdeveloped social infrastructure. The reasons for such conditions in rural areas are often the following: remoteness from regional centres, i.e., their peripheral nature; the absence or scarcity of facilities in the service sector; lack of transport accessibility to various services - educational, medical, domestic, cultural, etc.

\section{Research Methodology}

Consequently, all this gives a clear understanding of the need to solve extremely acute and important tasks at the scientific and practical level for the development of rural infrastructure.

This scientific research was carried out using traditional methods - monographic, expert assessment, comparative analysis, statistical, etc. The main social indicators, which are the main indicators of the development of rural infrastructure, were analyzed.

\section{Research Results}

Currently, the term "infrastructure" is understood as a whole system of interrelated industries and activities that are not related to production, but designed to service the manufacturing sector (material production) and contribute to the scientific, technical and social development of territories [10]. Many scientists reduce the author's hypothesis to the difference between social infrastructures for the production and non-production sectors (Fig. 1) $[5]$.

Based on the classification of social infrastructure facilities outlined in Figure 1, it should be noted that all of them, despite the division into production and non-production purposes, are interconnected and partially interchangeable. Considering the affiliation of the subject under study (social infrastructure) to the agrarian sector and rural territories, it should be noted that it is influenced by a number of factors that are characteristic only of rural 
territories. First of all, these are cultural features, as well as traditions and customs of the population [7].

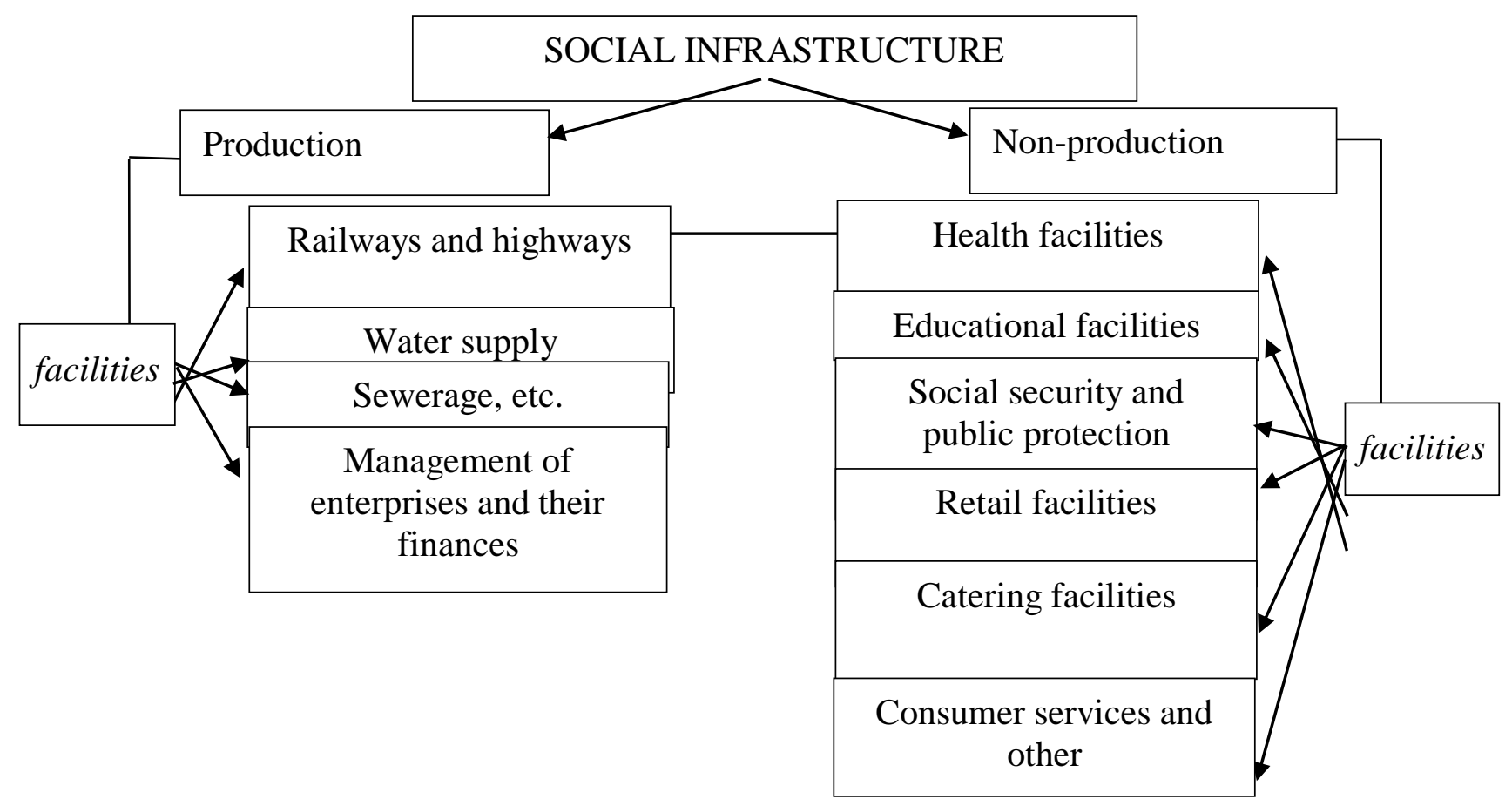

Fig. 1. Key elements of social infrastructure

Along with these factors, one should consider other features that are relevant at the present time, peculiar to rural areas, and cannot belong to urban territories [11]. For example, in rural areas there is a low population and negative demographic dynamics in relation to migration flows. Also, rural areas are characterized by a low degree of improvement of households, and the number of social services is limited. It is important to consider that the characteristic feature of rural area residents is permanent employment, which is due not only to social work, but also to household management.

However, in determining its functional significance, a social infrastructure is single and has a universal sense of impact [1]. The most significant functions of social infrastructure should be divided into three main blocks.

$1^{\text {st }}$ block: Creating a favourable environment for the population by protecting their health and information and advisory services.

$2^{\text {nd }}$ block: Training of highly qualified personnel due to formation of public awareness of the attractiveness and significance of labour in rural areas and agriculture, as well as the provision and attraction of scientific developments (projects), and the provision of business services.

$3^{\text {rd }}$ block: Reproduction of the working-age population. Within the framework of this block, the distribution and exchange of material goods and the provision of the required consumer services for the population are ensured.

One way or another, but the above social infrastructure functions directly and indirectly confirm the presence of a strong relationship between production and social infrastructure. In Russia, the development of rural social infrastructure sectors is related to almost 40 million residents of Russia (Figure 2). 


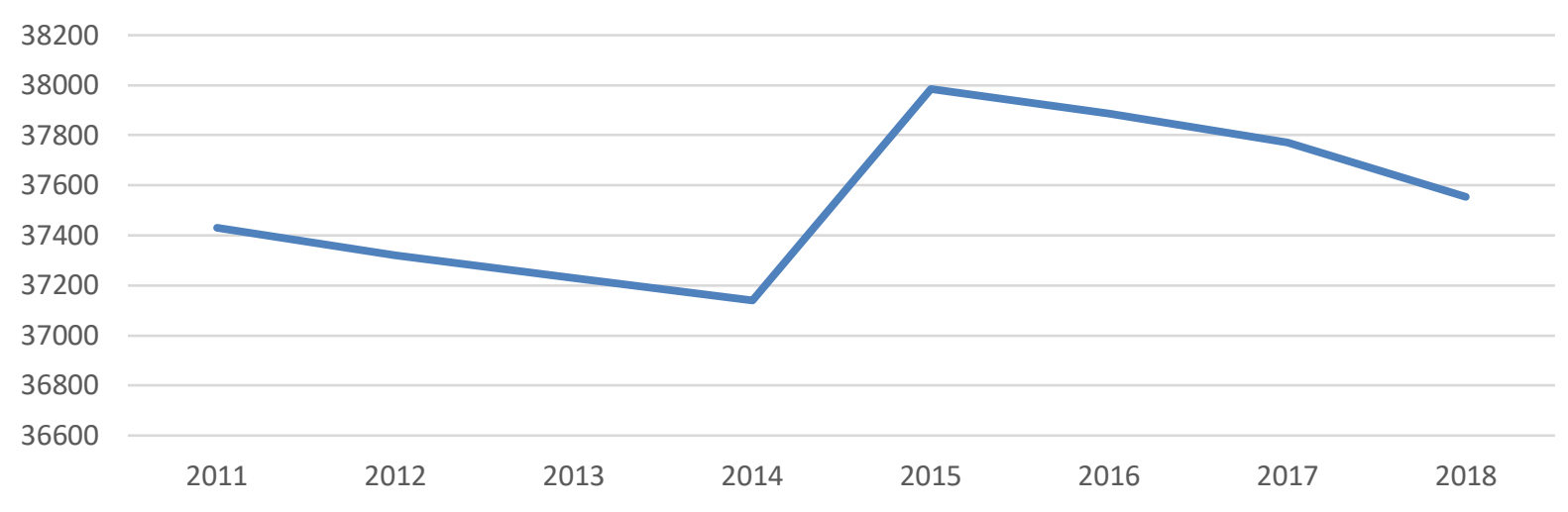

Fig. 2. The rural population of Russia, thousand people

Thus, according to Figure 1, it can be noted that for the period of 2018, the share of the rural population among the total number of citizens of the Russian Federation is $25 \%$ and over the past four years has a decline. So, for example, the number of villagers has been decreased by 218.5 thousand persons over the last reporting period. The main reasons for this negative situation are:

- Natural decline;

- Administrative-territorial transformations;

- Migration outflow.

Along with this analytical material, it is also seen that in the period from 2014 to 2015 there was a sharp increase in the number of rural residents, which is explained by the incorporation of the Republic of Crimea into Russia.

Of the total number of rural residents, 47\% (17777 thousand people) belong to the economically active population, of which $92 \%$ are employed, while their age ranges from 15 to 72 years, and the remaining $8 \%$ belongs to the category of unemployed. Regarding the latter category, it should be noted that approximately $25 \%$ of the total number of unemployed villagers are parasites, as they are not ready to proceed with it, subject to its availability and do not attempt to search for it.

Currently, against the background of the general negative social situation in the rural areas, it is important to note that some reasons for the migration of the population from rural areas are associated with low incomes in the agricultural sector of the economy (Table 1).

Table 1. Per capita disposable income of households in urban and rural areas, roubles *

\begin{tabular}{|l|c|c|c|c|c|c|c|c|c|}
\hline Indicators & \multicolumn{10}{|c|}{ Years } & $\begin{array}{c}\text { Absolute } \\
\text { deviation of } \\
2018 \text { to } \\
2011,+/-\end{array}$ \\
\cline { 2 - 10 } & 2011 & 2012 & 2013 & 2014 & 2015 & 2016 & 2017 & 2018 & +744 \\
\hline Village & 11745 & 13320 & 14191 & 15802 & 16639 & 16971 & 18309 & 19190 & +7445 \\
\hline City & 18291 & 20405 & 23645 & 25347 & 25466 & 26719 & 27206 & 29557 & +11266 \\
\hline \multicolumn{8}{|c|}{ In prices of the base 2011 } \\
\hline Village & 11745 & 12499 & 12507 & 12507 & 11664 & 11288 & 11880 & 11943 & +198 \\
\hline City & 18291 & 19147 & 20839 & 20062 & 17851 & 17772 & 17652 & 18394 & +103 \\
\hline
\end{tabular}

* Per one household member

Based on the data in Table 1, it can be noted that a serious gap between the size of the incomes of rural and urban residents is 1:1.33. Meanwhile, the nominal size of income is growing both in residents of that and another category of locality, but if we consider the most significant indicator of real incomes from a socio-economic point of view that can improve the level and quality of life in terms of consumption, we can note a practically negative 
situation. In rural areas, real incomes increased slightly - for eight years only by 198 roubles, and for urban residents, it decreased by 639 roubles.

Of course, it is impossible to improve the level and quality of life with income alone. That is why it is important to consider what is the state of the social sphere facilities in Russian hinterland, and how accessible they are to the population. According to Rosstat, we should note a positive trend (up 10\%) for the last 8 years in relation to housing, that is 1.004.200.000 $\mathrm{m}^{2}$, to the level of 2018 while about $72 \%$ are individual houses, $27 \%$ apartment buildings, and the remaining share is in other residential units including dormitories. It is important to note that the increase in the total housing stock in rural areas is proceeding more rapidly than in the city, which is primarily due to individual housing construction, mainly of the wooden type.

This positive situation easily changes in the representation of the state of housing improvement with the help of significant social infrastructure facilities (Figure 3).

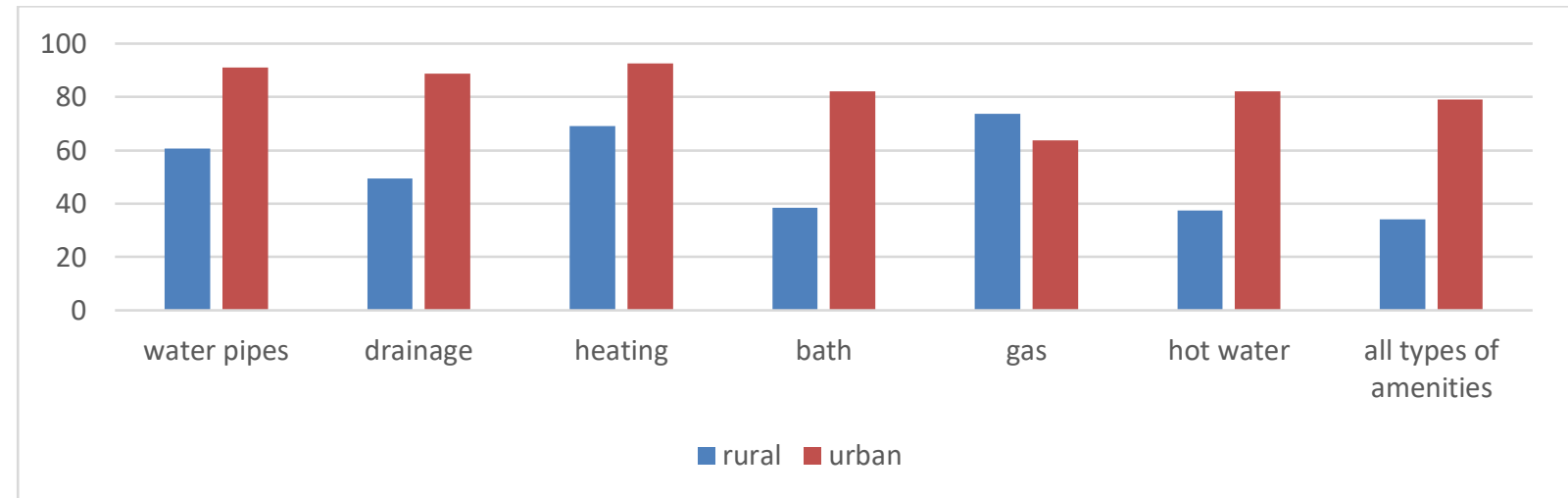

Fig. 3. Provision with types of housing improvement of urban and rural residents in 2018, \%

Housing in rural areas is improving due to the implementation of the federal target program "Sustainable development of rural territories for 2014-2017 and for the period until 2020" (hereinafter the Program). Currently, this program is somewhat reorganized and included as a subprogram in the State Program for the development of agriculture [3, 12].

In both urban and rural areas, the problem with pre-school educational institutions remains urgent. In particular, over the past eight years, their number in rural areas has decreased by $18 \%$ (3,5 thousand units). Within the framework of public-private partnerships and against the background of grant support, a private form of preschool educational institutions is developing, but their number is still small and amounts to only $0.5 \%$ (108 organizations) with a total number of 6065 pupils. Along with this, statistics also show a decrease in the number of middle-level educational institutions, the main reason for this, for the most part, is the process of enlargement (association). The situation with regard to schools remains critical, as evidenced by elementary statistics indicating an acute shortage of schools. Thus, on average 18 schools are accounted per 100 villages in Russia. Today, more and more propaganda are being conducted on the need to form a digital economy, familiarity with the elements of which should be provided in schools. Meanwhile, in Russian secondary schools there is an availability of access to the Internet as the basis of information resources at the level of $85 \%$, and only half of educational institutions have their own websites.

Along with education, the health problem remains unresolved in rural areas. Rosstat notes the more intensive dynamics in the reduction of local medical and obstetrical stations (MOSs), by 1288 units from 2012 to 2018. Hospitals of medical districts are of predominant significance, but their number was also declining, by 234 hospitals in the period of 20122018.

On the whole, the education and medicine fields in rural areas are problematic not only in terms of providing facilities themselves, but also in terms of personnel potential, the deficit of 
which sometimes is the main problem in a particular locality. Along with primary needs, the villagers also need social and cultural enrichment. In rural areas, more than 37,8 thousand cultural and leisure facilities are currently operating. If compared to 2012, this figure was equal to 38,5 thousand units. However, it should be noted that the restructuring of the Program funds allowed the situation in the field of culture in the rural areas since 2015 to change, when the number of studied facilities was reduced to 535.4 thousand units. It should be noted that the total number of employees of these organizations during the Program period has decreased, but the number of key specialists in cultural and leisure activities is growing dynamically and makes up 70,9\% of the total labour force in 2018, against 45,6\% in 2012.

The planned implementation of the directions of the Program for Sustainable Development of Rural Areas makes it possible to maintain throughout the entire period of its activity the field of physical education and sports through the construction of new sports facilities, including plane open sports facilities at the level of 19.2 thousand units and 65 thousand units respectively. The attention of the state and the Government regarding the implementation of this direction of the Program and the promotion of a healthy lifestyle in rural areas make it possible to involve an increasing number of rural residents in sports due to the availability of sports facilities for social infrastructure. For example, in 2018, in rural areas there were 32,5\% of residents who are constantly involved in sports, while in 2012 this value was only $20 \%$ [9].

Funds allocated from budgets of different levels for the implementation of the Program are quite voluminous, but require more and more control over their use, as well as the quality of the results of socio-economic development in rural areas (Table 2).

Table 2. Financing the main directions of the Program in 2014-2018 [8]

\begin{tabular}{|c|c|c|c|c|}
\hline \multirow[t]{3}{*}{ Program Directions } & \multicolumn{4}{|c|}{ Actually, financed funds, million roubles } \\
\hline & \multirow[t]{2}{*}{ Total } & \multicolumn{3}{|c|}{ including } \\
\hline & & federal budget & $\begin{array}{l}\text { the budgets of } \\
\text { the subjects of } \\
\text { the Russian } \\
\text { Federation }\end{array}$ & $\begin{array}{l}\text { extrabudgetary } \\
\text { sources }\end{array}$ \\
\hline $\begin{array}{l}\text { Improving the living } \\
\text { conditions of residents in } \\
\text { rural areas }\end{array}$ & 75481,96 & 19947,4 & 21507,09 & 34027,47 \\
\hline Gasification in rural areas & 12715,55 & 5193,62 & 6267,21 & 1254,72 \\
\hline Water supply development & 13596,44 & 5911,99 & 7053,14 & 631,31 \\
\hline $\begin{array}{l}\text { Development of a network } \\
\text { of educational } \\
\text { organizations }\end{array}$ & 8595,28 & 3057,94 & 5516,24 & 21,1 \\
\hline $\begin{array}{l}\text { Development of a network } \\
\text { of medical and obstetrical } \\
\text { stations }\end{array}$ & 2853,12 & 816,45 & 1901,73 & 134,94 \\
\hline $\begin{array}{l}\text { Development of a network } \\
\text { of plane sports facilities in } \\
\text { rural areas }\end{array}$ & 1459,28 & 625,75 & 789,68 & 43,85 \\
\hline $\begin{array}{l}\text { Development of a network } \\
\text { of cultural and leisure } \\
\text { facilities }\end{array}$ & 1542,91 & 873,7 & 668,99 & 0,22 \\
\hline $\begin{array}{l}\text { Road network } \\
\text { development }\end{array}$ & 45503,76 & 25273,72 & 20204,2 & 25,84 \\
\hline $\begin{array}{l}\text { Implementation of projects } \\
\text { for the construction of } \\
\text { compact housing sites }\end{array}$ & 8517,93 & 4176,99 & 4142,43 & 198,51 \\
\hline $\begin{array}{l}\text { Grant support for local } \\
\text { citizens' initiatives }\end{array}$ & 1374,77 & 370,68 & 610,97 & 393,12 \\
\hline
\end{tabular}




\section{Conclusions and Proposals}

Based on the data in Table 2 and in general on the results of the target Program, it can be stated that the Program focuses on the relationship between the economy and the social sphere in rural areas. Firstly, the development of social infrastructure gives attractiveness to the rural areas, the desire to live and work there, which means that the production sector minimizes or eliminates the problem with an acute shortage of qualified specialists. Secondly, the objects of social infrastructure themselves create an image and an opportunity for rural areas to be innovative and investment attractive. Thirdly, it is an opportunity to create more jobs for the population. The following strategic measures to improve social infrastructure should be:

- Continue to provide rural settlements with modern paved roads;

- Create a comfortable and at the same time optimal transport connection with other objects of social infrastructure;

- Provide ubiquitous telephone communications and Internet resources;

- Improve the condition of housing and provide it with all necessary communal amenities;

- Everywhere to ensure the accessibility of institutions of medicine, education, cultural and leisure type, etc.

\section{REFERENCES}

[1] Determinants of household food insecurity in Mexico/Megana-Lemus D., Isidoro A., Rosson C.P., Lara-Alvarez J. // Agricultural and food Economics. 2016. Vol. 4. Pp. 4-10

[2] Gafarova M.R. Buranov O., Rizoeva O. State of rural social infrastructure and modern directions of its development // Bulletin of the Tajikistan Technological University. 2016, No. 2(27). Pp. 63-69.

[3] Gerasimov A.N., Kapustina E.I., Grigoryeva O.P. Statistical evaluation of the socio-economic development indicators of certain Stavropol region territories // Social and economic development of Russia and regions in statistics: Materials of the $\mathrm{V}$ international scientific and practical conference. In 2 volumes. 2019. Pp. 56-65.

[4] Kapinos, R., Dobrunova, A., Akupiyan, O., Kravchenko, D. Distinctive features of classification of factors determining the economic behavior of economic entities predominantly rural areas from the standpoint of the theory of long waves//International Review 2018. No. 3-4. pp. 26-34.

[5] Kovalenko E.G., Koroleva Yu.G. Problems of social infrastructure development of rural territories in the Republic of Mordovia // Fundamental Research. 2018. No. 10. Pp. 79-84.

[6] Kuzmich N.P. The development of social infrastructure in rural areas of the region in order to improve the quality of life of the population // Economics yesterday, today, tomorrow. 2019. Vol. 9. No. 4-1. Pp. 392-399.

[7] Muravyova M.V. Methodological principles of the rural social infrastructure study // Agricultural Scientific Journal. 2015. No. 10. Pp. 90-94.

[8] On the implementation of the federal target program "Sustainable development of rural territories for 2014-2017 and for the period until 2020" in 2014-2017. M.: FSINI "Rosinformagroteh", 2018. P. 120.

[9] On the state of rural territories in the Russian Federation in 2018. Annual report on monitoring results: scientific publication - M.: FSINI Rosinformagroteh, 2020, issue 5, p. 336.

[10] Spanova B.K. Theoretical and methodological aspects of a social infrastructure study. Economics // Bulletin of KarSU. 2007. pp. 12-23.

[11] Yarkova T.M. Social and economic availability of food for the population of the region: methodical aspect // The Turkish Online Journal of Design, Art and Communication - TOJDAC ISSN: 2146-5193, March 2018 Special Edition, pp. 219-225.

[12] Yarkova T.M. The results of the rural territories development in the regions of the Volga Federal District // Economics of agricultural and processing enterprises. 2019. No. 6. Pp. 51-55.

[13] Yusufov R.A. Socio-economic efficiency of improving governance in the region // Economics, labour and management in agriculture. 2015. No. 4 (25). Pp. 94-97.

\section{Article history:}

Received 15 November 2020

Accepted 16 December 2020 